\title{
Changes in students' choice determinants in Poland: a comparative study of tertiary business education between 2008 and 2013
}

\author{
Bogdan Sojkin • Paweł Bartkowiak • Agnieszka Skuza
}

Published online: 11 July 2014

(C) The Author(s) 2014. This article is published with open access at Springerlink.com

\begin{abstract}
For the last 20 years Polish education faced turbulent changes, first experiencing a rapid increase in the number of students and the dynamic growth of educational institutions, and then facing the reverse trend of decreasing number of students and universities being closed down or facing serious financial problems. Furthermore, forecasts for the next 10 years predict that most of the non-public universities in Poland will experience serious problems to survive in the market. Facing new challenges, universities changed the way they think about their students and the customer-oriented approach became the dominant management imperative for most of them. Ability to understand the reasons behind students tertiary education decisions emerged as a key issue in increasing enrollments. Predicting students choice determinants may be however more difficult than expected as those choices are dynamic and might change over time. While the literature on the university choice factors is growing, still little is evidenced with regard to the dynamism of the tertiary education decision making process and this article is aimed to contribute to filling this gap. We identified that both aspects of students decision making process-pursuing tertiary education and the choice of the particular university - are a subject of change over time and might be conditioned on economic, social and demographic changes of the given market.
\end{abstract}

Keywords Educational choices · Higher education · Gender differences

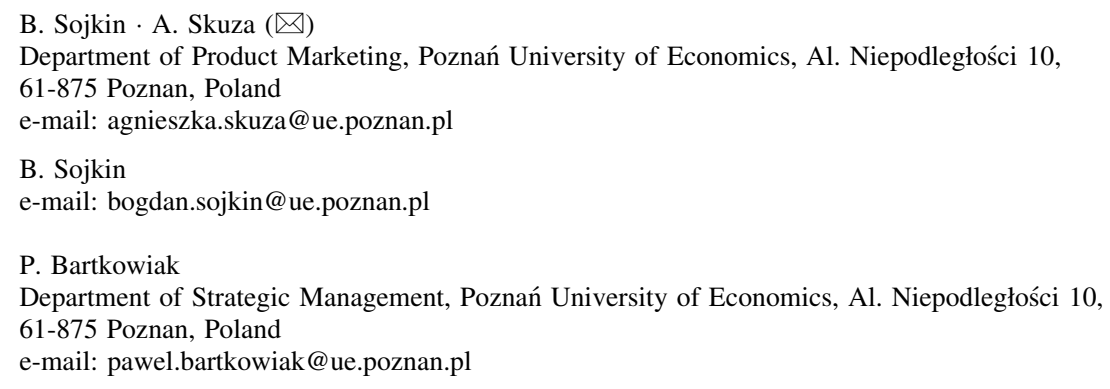




\section{Introduction}

The past decades brought tremendous changes in higher education in Poland. The increased demand for higher education was the result of economical, political and social transformation that Poland has gone through since the collapse of communism in 1989. First, the departure from "elitist labour market-led polytechnic system" (Koivula and Rinne 2006) was evidenced as Poland needed different kind of skills needed to lead the companies on a new market-economy (Skuza et al. 2013). Therefore business education grew in importance and indeed it was a huge demand for new education fields such as marketing, management, finance or logistics. Second, the increasing demand for education could not be satisfied by public universities that were the only educational institutions in the communist era. The new law that was introduced in 1990 allowed non-public universities to be founded and as the result between 1990 and 2010 the number of higher education institutions increased more than four times from 112 (in 1990) to 460 (in 2010), constituting the biggest private higher education system in Central-Eastern Europe (Kwiek 2013). Out of 460 universities 330 were non-public, although public universities educated $71 \%$ of the total number of students. The growth in the number of universities was the result of a $500 \%$ increase in the number of students-from 404,000 in 1990 to over 1,950,000 in 2005 (Sojkin et al. 2012; Rozanski 2008; CSOP 2010), which allowed Poland to achieve one of the highest gross enrolment ratio (GER) in the OECD countries $(54 \%)$ (OECD 2009; Antonowicz and Gorlewski 2011).

However, this growth ended in 2006 when, for the first time in the post-communist Polish history, a steady decline in the number of students begun, followed by the decrease in the number of private schools which started in 2011. Contraction of the fee-based private sector (full-time studies in public sector are tuition free) was first to follow the decline in the enrolment level (Kwiek 2013). According to Polish Ministry of Science and Higher Education until 201349 non-public universities closed down or were under liquidation (Polish Ministry of Science and Higher Education website, derived 31.03.2013). Furthermore, the demographic forecasts place Poland among European countries with the highest decreases in population (UN Report 2005; Eurostat 2010). For example, in 2010 the number of population aged between 19 and 24 , which constitute $70 \%$ of all university candidates, decreased to 3.4 million (comparing to 3.9 million in 2002), which will further decrease to 2.3 million in 2020 (CSOP 2009). The number of people below 19 years old will drop from 8.3 million in 2010 to 7.7 million in 2020 and 7.2 million in 2030 .

Demographic trends will directly influence changes in the education sector (OECD 2008). First, with GER reaching $54 \%$, the number of students is predicted to drop in 2020 by almost $30 \%$ when compared to 2011, resulting in the substantial decrease in the number of universities, particularly non-public (Newsweek 2012). The fall in enrolment level in Poland is projected to be the highest in Europe and only comparable to that in other post communist countries (Kwiek 2013). Second, ageing population leads to changes in public spendings. While the society is getting older public spendings on education become smaller and spendings benefiting older people directly became larger (Ernst\&Young and Instytut Badan nad Gospodarka Rynkowa 2010). According to OECD data in 2020 in Poland public spendings on higher education will drop to $1.1 \%$ of gross domestic product (GDP) while in 2005 they constituted $1.6 \%$ of GDP (OECD 2008). Third, according to Ernst\&Young and Instytut Badan nad Gospodarka Rynkowa (2010) the proportion of people with university degree within the age group of 25-64 will increase from $17 \%$ in 2008 to $25-30 \%$ in 2025, what can lead to decrease in demand for higher education. 
The saturation of higher education sector, along with pessimistic demographic forecasts that have already begun to impact the system contraction, changed the way universities think about their students. The "student as a customer" approach is more valued than ever before and understanding applicants' university choices became one of the most important imperatives for the university management (Brown and Mazzarol 2009; Maringe 2006; Douglas et al. 2006). However, predicting students choice factors may be more difficult than expected as those choices are dynamic and might change over time. Our research is aimed not only to diagnose the determinants behind tertiary education choices, but also to identify how those determinants changed over a 5-year period of time (2008-2013).

The literature on the university choice motives is growing, but even so, still little is evidenced with regard to the dynamism of the tertiary education decision making process. Current literature mainly focus on explanation of educational choices and the leading works in the field investigate the issue from a rational choice perspective (McCoy and Smyth 2010). It states that people maximize the fulfilment of their needs on the basis of their perception of the situation (Elster 1999; Sullivan 2006). To explain secondary education graduates' choices when pursuing higher education the relevant studies in the field often use human capital theory (Menon et al. 2007; Hung et al. 2000; Jimenez and SalasVelasco 2000; Wong 1989). Examining the perceived costs and benefits of educational choices is a leading theme in their studies. While the perceived utility of different alternatives is a key assumption for economists and psychologists, economists concentrate more on available income, future earnings expectations or employment opportunities, and psychologists focus more on importance of personal characteristics and scholastic abilities (Jimenez and Salas-Velasco 2000). Sociologists, on the other hand, deter themselves from cost and benefit approach, explaining tertiary educational decisions based on the social background, such as educational and professional level of parents, or family economic situation (Cea and Mora 1992; Gonzalez and Davila 1998; Pimpa 2005). These approaches are not mutually exclusive and all groups of factors can explain tertiary educational choices. What they usually miss to explain is how those choices change over time due to the dynamism of economical and social situation of a given market. Unemployment rates, the consequences of financial and economic crisis that dominated the world for the last few years, demographic changes, or changing generational needs may influence the value of university degree and the reasons behind enrolment rates. In Poland in 2012 economic situation worsened. While in 2008 Polish economy was growing and remained the only economy with positive growth among all EU-27 countries, in 2012 Poland joined global recession with the result of Polish economy growth slowing down, unemployment growing (from $7 \%$ in 2008 to $14 \%$ at the beginning of 2013), and businesses expecting further freeze in their employment policies (European Economic Forecast 2012; CSOP 2013; International Quarterly Statistics 2008). We believe that such unfavourable market conditions might have resulted in changes of university candidates' expectations and motives behind their tertiary education choices.

Following findings of other researchers on post-secondary students' choices (Cremonini et al. 2008; Cabrera et al. 2008; Chen 2007; Menon et al. 2007; Menon 2004; Kohn et al. 1976; Chapman 1986; Jackson 1982; Hossler and Gallagher 1987; Hanson and Litten 1982; Somers et al. 1999; Mintzberg et al. 1976; Wedley and Field 1984), in this article we focus on two phases of the higher education choice process. We identify factors behind pursuing business tertiary education and factors that lead to the university choice. The unique contribution of this paper lies in the identification of dynamism of preferences in higher education choices and we use 2008 and 2013 as the compared periods. While economic and demographic conditions vary over time the reasons behind the choices 
associated with higher education may also change and in this paper we would like to present the results of our findings in this area. We believe our findings will not only help higher institutions' management to get more complete understanding of their "customers", but also to attract their attention to the dynamism of choices associated with higher education.

This paper is organized as follows: In the next section the methodology of our study is explained in detail and both qualitative and quantitative research methods are presented, along with characteristic of the sample and statistical analysis. This is followed by research findings. Then we draw main conclusions discussed within the specific Polish context. Finally, we present implications and limitations of our study.

\section{Method}

The exploratory character of our study in both researched periods of 2008 and 2013 combined two methods. First, to understand how students make their tertiary education choices, focused groups were used. We chose to conduct focus groups in both researched periods to identify the possible changes in the declared choice factors. Focus groups sessions were carried out in January/February 2008 and January 2013. As in 2008, focus groups in 2013 were based on a semi-structured interview process with the use of the interview guide with the same list of questions. In both research periods we conducted 15 focus groups with each group including ten participants recruited from public and nonpublic universities located in the Wielkopolska region. Focus groups that we moderated in 2008 helped us to collect information how Polish students make their university choices (Sojkin et al. 2012), and focus groups that we conducted at the beginning of 2013 allowed us to identify several additional determinants, not mentioned by focus groups participants in 2008.

In the quantitative study that followed the qualitative focus group sessions, we used a survey instrument. The quantitative study was carried out in April-June of 2008 and AprilMay 2013. In 2008 we built a questionnaire based on focus group discussions and a review of previous research findings about students educational choices (Sojkin et al. 2012). Relevant literature in the field was used which was based on economic models (based on the idea of rational cost-benefit analysis), sociological models (related to aspirations, family conditions, school environment, etc.) or combined models (Hossler et al. 1999; Jackson 1982; Kohn et al. 1976; Chapman 1986; Hanson and Litten 1982; Hossler and Gallagher 1987; Cremonini et al. 2008; Chen 2007; Hung et al. 2000). As in 2008, the questionnaire that we used in 2013 was divided in three main parts. Following focus group study conducted at the beginning of 2013, we added new statements to our 2008 questionnaire. Overall, the questionnaire we used in 2013 had 31 (23 in 2008) statements describing reasons behind pursuing higher education, 39 (27 in 2008) measured the significance of variables determining decisions about choice of a university, and 43 (34 in 2008) measured the satisfaction factors from studying in a chosen university. Students were also asked about the main sources of information they used while making their university choice (internet, rankings, university brochures, friends' recommendations, campus visits, etc.). In both researched periods respondents were also asked about their personal data such as gender, age, type of targeted university (public or non-public), family average income level, and place of living prior to studies (village or a city). 


\section{Sample}

Quantitative data was collected in 2008 and in 2013. The questionnaire was distributed to students of business majors in 16 public and 24 private universities in the Wielkopolska region (the same for both researched periods). Quota sampling was used to choose the sample (for more detail please see Sojkin et al. 2012). Sample characteristics are presented in Table 1. In 2008 out of a total of 2,350 surveys sent, 1,420 usable questionnaires were received and 2013 out of 2,200 questionnaires sent, we received 1,594 complete questionnaires. Chi square goodness of fit test confirmed that in both researched periods our sample distribution did not differ significantly from the general distribution.

\section{Statistical analysis}

After the instrument was tested and received the required parameters as for unidimensionality of the scale, and reliability and consistency of the inter-item reliability, the researchers conducted the main study. To test the scale's construct validity, the exploratory factor analysis (EFA) was performed. The Kaiser-Meyer-Olkin (KMO) measure of sampling adequacy and Bartlett's Test of Sphericity (BTS) proved that the data set of all groups of determinants was suitable for factor analysis. The extracted factors with eigenvalues $>1$ are presented in Table 2, along with their reliability measures (with items loadings on each factor reaching .60 or more). Although the survey also covered satisfaction determinants, in this article we limited our comparative analysis to the choices behind pursuing higher education and the choice of the university. With regard to the choice of pursuing higher education our statistical analysis extracted seven factors (with two new factors identified in 2013). University choice statements, on the other hand, loaded in ten factors (with three new factors identified in 2013).

In the next section we will present our main findings with regard to the general differences in university choice motives. We will also present those differences controlled for gender as we find it important to inform university deciders about potential differences in messages sent to female and male candidates. Further we will show the differences of choice motives controlled for university type, which are particularly important in Poland and other post-communist countries due to extensive dynamic of public/private educational sector and similar demographic trends in those countries.

To compare data from both researched periods the independent $t$ test was performed (also called the two sample $t$ test or student's $t$ test) which is an inferential statistical test that determines whether there is a statistically significant difference between the means in two unrelated groups.

\section{Results}

Determinants behind the decision to pursue tertiary education

Our data from 2008 and 2013 show that decisions about pursuing higher education were influenced by five factors in 2008 and seven factors in 2013 (with two new factorsrecognition and prestige, and gaining work experience during studies). General data show that in 2013 two factors fell down in their significance when compared to 2008-studenttype of life and family opinion and expectations (Table 3). 
Table 1 Sample Characteristics (\%)

\begin{tabular}{|c|c|c|c|c|c|}
\hline & 2008 & 2013 & & 2008 & 2013 \\
\hline Gender & & & Income & & \\
\hline Male & 38 & 39 & Less than country average & 21 & 25 \\
\hline \multirow[t]{2}{*}{ Female } & 62 & 61 & Country average & 50 & 46 \\
\hline & & & More than country average & 27 & 29 \\
\hline Age group & & & Place of living & & \\
\hline Less than 19 years & 18 & 18 & City & 66 & 62 \\
\hline 20-29 years & 65 & 68 & Village & 34 & 38 \\
\hline 30 years and over & 17 & 14 & & & \\
\hline \multicolumn{6}{|l|}{ Type of university } \\
\hline Public university & 46 & 51 & & & \\
\hline Non-public university & 54 & 49 & & & \\
\hline
\end{tabular}

Table 2 Exploratory factor analysis results-2008 and 2013

\begin{tabular}{|c|c|c|c|c|c|c|}
\hline & \multicolumn{2}{|c|}{ No. of items* } & \multicolumn{2}{|c|}{ Loadings } & \multicolumn{2}{|c|}{ Cronbach's $\alpha$} \\
\hline & 2008 & 2013 & 2008 & 2013 & 2008 & 2013 \\
\hline \multicolumn{7}{|l|}{ Choice of pursuing higher education ${ }^{\mathrm{a}, \mathrm{d}}$} \\
\hline Student-type of life & 4 & 4 & $.64-.78$ & $.61-.80$ & .800 & .899 \\
\hline Family opinion and expectation & 3 & 3 & $.61-.77$ & $.61-.81$ & .759 & .853 \\
\hline Professional advancement & 4 & 4 & $.64-.70$ & $.64-.77$ & .744 & .768 \\
\hline Better chances to find a job & 3 & 3 & $.64-.69$ & $.61-.70$ & .704 & .795 \\
\hline Family financial support & 2 & 2 & $.62-.79$ & $.73-.82$ & .717 & .718 \\
\hline Recognition and prestige & - & 3 & - & $.63-.78$ & - & .701 \\
\hline Gaining work experience during studies & - & 3 & - & $.61-.65$ & - & .729 \\
\hline \multicolumn{7}{|l|}{ Choice of a university ${ }^{b}$ e } \\
\hline Professional advancement & 4 & 4 & $.81-.83$ & $.63-.82$ & .878 & .874 \\
\hline University tradition & 3 & 3 & $.65-.73$ & $.61-.78$ & .777 & .816 \\
\hline University reputation & 4 & 4 & $.69-.70$ & $.61-.73$ & .701 & 694 \\
\hline Marketing efforts & 4 & 4 & $.62-.77$ & $.62-.74$ & .743 & .782 \\
\hline Courses offered & 4 & 4 & $.62-.76$ & $.60-.81$ & .702 & .704 \\
\hline Cost of studies and accessibility of financial aid & 3 & 3 & $.66-.74$ & $.66-.77$ & .712 & .721 \\
\hline Family opinion and expectations & 3 & 3 & $.73-.75$ & $.82-.83$ & .711 & .834 \\
\hline University culture/atmosphere & - & 5 & - & $.61-.77$ & - & .795 \\
\hline Educational process & - & 3 & - & $.60-.74$ & - & 653 \\
\hline Social and educational facilities & - & 3 & - & $.60-.81$ & - & .764 \\
\hline
\end{tabular}

2008: ${ }^{a}$ Cumul. variance extracted 51.1\%; KMO-.846; Bartlett's test of sphericity: $\chi^{2}=7827.903$; $d f=253 ; p \leq .001$

b Cumul. variance extracted 56.8 \%; KMO_.887; Bartlett's test of sphericity: $\chi^{2}=16356.439 ; d f=561$; $p \leq .001$

2013: ${ }^{\mathrm{d}}$ Cumul. variance extracted $59.8 \%$; KMO-.905; Bartlett's test of sphericity: $\chi^{2}=22433.635$; $d f=561 ; p \leq .001$

e Cumul. variance extracted 63.9\%; KMO-.898; Bartlett's test of sphericity: $\chi^{2}=26955.881 ; d f=903$; $p \leq .001$ 
Table 3 Determinants of the choice to pursue tertiary education-general and controlled for gender

\begin{tabular}{llllll}
\hline Choice (2008 and 2013) & General & Female & Male & $t$ statistic & $p$ value \\
& $\mathrm{N}=1420$ & $\mathrm{~F}(\sigma)$ & $\mathrm{M}(\sigma)$ & \\
& $(2008)$ & $\mathrm{N}=885(2008)$ & $\mathrm{N}=535(2008)$ & \\
& $\mathrm{N}=1594(2013)$ & $\mathrm{N}=970(2013)$ & $\mathrm{N}=624(2013)$ & \\
\hline
\end{tabular}

Student-type of life

$\begin{array}{llllrl}2008 & 3.62(.88) & 3.76(.84) & 3.36(.88) & 8.39 * * * & .000 \\ 2013 & 2.69(.90) & 2.60(.90) & 2.82(.89) & -4.82 * * * & .000 \\ & 2008>2013 * * * & F 08>F 13 * * * & M 08>M 13 * * * & & \end{array}$

Family opinion and expectations

\begin{tabular}{|c|c|c|c|c|c|}
\hline 2008 & $3.69(.86)$ & $3.73(.86)$ & $3.62(.84)$ & $2.34 *$ & .020 \\
\hline \multirow[t]{2}{*}{2013} & $2.38(.92)$ & $2.35(.92)$ & $2.43(.93)$ & -1.71 & .087 \\
\hline & $2008>2013 * * *$ & $F 08>F 13 * * *$ & $M 08>M 13 * * *$ & & \\
\hline \multicolumn{6}{|c|}{ rofessional advancement } \\
\hline 2008 & $1.83(.51)$ & $1.78(.48)$ & $1.91(.54)$ & $-4.77 * * *$ & .000 \\
\hline \multirow[t]{2}{*}{2013} & $4.02(.59)$ & $4.07(.56)$ & $4.03(.62)$ & 1.06 & .37 \\
\hline & $2008<2013 * * *$ & $F 08<F 13 * * *$ & $M 08<M 13 * * *$ & & \\
\hline \multicolumn{6}{|c|}{ etter chances to find a job } \\
\hline 2008 & $1.84(.73)$ & $1.81(.72)$ & $1.89(.74)$ & $-2.10 *$ & .04 \\
\hline \multirow[t]{2}{*}{2013} & $3.47(.75)$ & $3.49(.73)$ & $3.42(.79)$ & 1.81 & .071 \\
\hline & $2008<2013 * * *$ & $F 08<F 13 * * *$ & $M 08<M 13 * * *$ & & \\
\hline \multicolumn{6}{|c|}{ amily financial support } \\
\hline 2008 & $2.61(.85)$ & $2.60(.85)$ & $2.62(.84)$ & -.36 & .719 \\
\hline \multirow[t]{2}{*}{2013} & $3.07(.99)$ & $3.08(1.00)$ & $3.03(1.01)$ & .93 & .352 \\
\hline & $2008<2013 * * *$ & $F 08<F 13 * * *$ & $M 08<M 13 * * *$ & & \\
\hline \multicolumn{6}{|c|}{ ecognition and prestige } \\
\hline 2013 & $4.30(.65)$ & $4.33(.63)$ & $4.23(.67)$ & $3.10 * *$ & .002 \\
\hline \multicolumn{6}{|c|}{ Gaining work experience during studies } \\
\hline 013 & $2.82(.95)$ & $2.79(.93)$ & $2.85(.98)$ & -1.26 & .21 \\
\hline
\end{tabular}

$* p \leq .05 ; * * p \leq .01 ; * * * p \leq .001$; italic represents statistically important differences between 2008 and 2013

Three factors, on the other hand, increased significantly their impact on candidates' decisions_-professional advancement $(\mathrm{M}=4.02)$, better chances to find a job $(\mathrm{M}=3.47)$, and family financial support $(\mathrm{M}=3.07)$. We can also note that the most important factor influencing decisions about pursuing tertiary education was recognition and prestige $(\mathrm{M}=4.30)$ which did not appear in our previous study. Also, while in 2008 student-type of life and family opinion and expectations were the most important choice factors, in 2013 they lost in importance in favour of professional advancement and better chances to find a job, which beside recognition and prestige became key determinants of pursuing university education.

When controlled for gender, differences between men in 2008 and 2013, and between women 2008 and 2013 mirror the general differences with the same tendencies regarding each factor. However, analysis of differences between men and women in a specific period of time changed. In 2008 we reported differences between men and women with regard to family opinion and expectations $[t(1,420)=2.34, p \leq .05]$, professional advancement 
Table 4 Determinants of the choice to pursue tertiary education controlled for university type

\begin{tabular}{|c|c|c|c|c|}
\hline Choice (2008 and 2013) & $\begin{array}{l}\text { Public } \\
P(\sigma) \\
N=760(2008) \\
N=810(2013)\end{array}$ & $\begin{array}{l}\text { Nonpublic } \\
\text { NP }(\sigma) \\
N=635(2008) \\
N=760(2013)\end{array}$ & $t$ statistic & $p$ value \\
\hline
\end{tabular}

Student-type of life

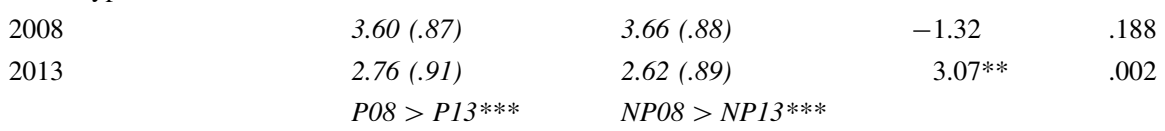

Family opinion and expectations

2008

$3.73(.85)$

2013

$2.38(.92)$

P08 $>$ P13***

Professional advancement

2008

2013

Better chances to find a job

2008

2013

Family financial support

2008

2013

Recognition and prestige

2013

$1.79(.48)$

$4.04(.58)$

$P 08<P 13 * * *$

$89(.54)$

$4.00(.59)$

1.61

.108

$2.39(.93)$

$-.27$

.784

NP08 $>N P 13 * * *$

$N P 08<N P 13 * * *$

$1.82(.69)$

$3.51(.73)$

P08 $<$ P13***

1.87 (.77)

3.42 (.77)

$-1.47$

$2.32 *$

NPO8 < NP13***

$2.57(.87)$

1.28

.200

3.08 (1.00)

$-.59$

$3.05(1.00)$

$N P 08<N P 13 * * *$

P08 < P13***

4.28 (.66)

$4.31(.64)$

$-.8$

Gaining work experience during studies

2013

$2.87(.94)$

$2.77(.96)$

$2.11^{*}$

.035

$* p \leq .05 ; * * p \leq .01 ; * * * p \leq .001$; italic area represents statistically important differences between 2008 and 2013

$[t(1,420)=-4.77, p \leq .05]$ and better chances to find a job $[t(1,420)=-2.10, p \leq .05]$. In 2013 those differences do not exist, which might suggest the convergence of opinions of both gender groups with regard to those issues.

Finally, when controlled for the university type (public vs. non-public), the study showed various changes between 2008 and 2013 (Table 4). In 2008 only professional advancement differentiated students' choices between public and non-public university. In 2013, three choice factors were statistically more significant for students while choosing public universitystudent-type of life, better chances to find a job, and gaining work experience during studies.

Information search and factors determining university choice

In this stage of the decision making process we focused on identification of the information sources that candidates use to search for information about different universities (Table 5), and we identified factors that contribute to the final choice of the specific university (Table 6). 
Table 5 Information sources

\begin{tabular}{lll}
\hline Information source & $\begin{array}{l}2008 \\
(\%)\end{array}$ & $\begin{array}{l}2013 \\
(\%)\end{array}$ \\
\hline Internet & 62.80 & 67.10 \\
University catalogue & 53.70 & 37.90 \\
Friends recommendations & 34.00 & 28.50 \\
Educational fairs & 30.60 & 17.70 \\
Campus visits & 20.10 & 29.40 \\
Advertisement in print media (magazines, daily & 18.80 & 3.60 \\
$\quad$ newspapers) & 8.00 & 5.80 \\
Opinions of high school teachers & & \\
\hline
\end{tabular}

Our research showed that two sources are more often used in 2013 than in 2008internet and campus visits. All other sources of information significantly decreased in importance with regard to the university choice.

Regarding the final decision about the choice of the specific university, our study identified ten factors-seven factors identified also in 2008, and three new ones that emerged in our study in 2013: university culture/atmosphere, social and educational facilities, and educational process (operationalized through teaching and learning methodologies and practices). Research results indicate that in 2013 the most important choice factors changed, with courses offered, university reputation, and cost of studies and accessibility of financial aid emerging as key factors. It should be noted that the mean of each of those key choice factors increased by over $80 \%$ in 2013 when compared to 2008. Our study also showed that two new factors-educational process, and university culture/ atmosphere-achieved mean values that placed them among the top five determinants of the university choice.

When controlled for gender, again we noticed the same convergence tendencies that we observed in tertiary education choice process (Table 6). The differences between men and women reported in 2008 concerned university reputation, courses offered, and cost of studies and accessibility of financial aid. Those differences were also noted in 2013, but they were much smaller.

Further differences were found when we controlled for the university type (Table 7). When we performed independent sample $t$ test, we found out that comparing to 2008 two factors-marketing efforts and cost of studies and accessibility of financial aid-stopped differentiate those respondents who targeted public universities from those who submitted their application to non-public universities. At the same time three new factors appeared to distinguish both groups of respondents in their tertiary institution choice-university tradition, courses offered, and family opinion and expectations.

\section{Discussion}

Our research has highlighted key factors behind two phases of the decision making process-decisions concerning pursuing tertiary education and those associated with the choice of a particular university. While literature on secondary school graduates' decisions on tertiary education is growing, still relatively little has been written about student choice determinants in former communist countries, with Poland, the largest CEE economy, being particularly underrepresented in the current research. Our study was aimed to fill this gap. 
Table 6 Determinants of the university choice-general and controlled for gender

\begin{tabular}{|c|c|c|c|c|c|}
\hline $\begin{array}{l}\text { University choice } \\
(2008 \text { and 2013) }\end{array}$ & $\begin{array}{l}\text { General } \\
N=1420 \\
N=1594\end{array}$ & $\begin{array}{l}\text { Female } \\
F(\sigma) \\
N=885(2008) \\
N=970(2013)\end{array}$ & $\begin{array}{l}\text { Male } \\
M(\sigma) \\
N=535(2008) \\
N=624(2013)\end{array}$ & $t$ statistic & $p$ value \\
\hline
\end{tabular}

Professional advancement

$\begin{array}{llllrr}2008 & 3.01(1.00) & 2.99(1.01) & 3.02(1.00) & -.470 & .638 \\ 2013 & 2.91(.90) & 2.91(.90) & 2.91(.89) & .079 & .937 \\ & 2008>2013^{*} & \text { F08 }=\mathrm{F} 13 & \text { M08 }>\text { M13* } & & \end{array}$

University tradition

$\begin{array}{llllrl}2008 & 2.96(.82) & 2.93(.83) & 3.00(.80) & -1.51 & .13 \\ 2013 & 3.17(.79) & 3.17(.76) & 3.15(.84) & .608 & .544 \\ & 2008<2013 * * * & F 08<F 13 * * * & M 08<M 13 * * & & \end{array}$

University reputation

$\begin{array}{llllrl}2008 & 2.09(.67) & 2.04(.64) & 2.17(.71) & -3.487 * * * & .001 \\ 2013 & 3.81(.60) & 3.84(.57) & 3.76(.63) & 2.489 * & .013 \\ & 2008<2013 * * * & F 08<F 13 * * * & M 08<M 13 * * * & & \end{array}$

Marketing efforts

$\begin{array}{llllcc}2008 & 2.80(.77) & 2.83(.80) & 2.76(.72) & 1.49 & .14 \\ 2013 & 2.99(.85) & 2.98(.85) & 3.00(.84) & -.258 & .796 \\ & 2008<2013 * * * & F 08<F 13 * * * & M 08<M 13 * * * & & \end{array}$

Courses offered

$\begin{array}{llllrr}2008 & 1.98(.55) & 1.93(.52) & 2.06(.60) & -4.202 * * * & .001 \\ 2013 & 3.85(.67) & 3.88(.65) & 3.78(.69) & 3.014 * * & .003 \\ & 2008<2013 * * * & F 08<F 13 * * * & M 08<M 13 * * * & & \end{array}$

Cost of studies and accessibility of financial aid

\begin{tabular}{|c|c|c|c|c|c|}
\hline 2008 & $1.98(.93)$ & $1.92(.90)$ & $2.08(.94)$ & $-3.233 * * *$ & .001 \\
\hline \multirow[t]{2}{*}{2013} & $3.63(.80)$ & $3.66(.78)$ & $3.57(.83)$ & $2.191 *$ & .029 \\
\hline & $2008<2013 * * *$ & $F 08<F 13 * * *$ & $M 08<M 13^{* * *}$ & & \\
\hline \multicolumn{6}{|c|}{ amily opinion and expectation } \\
\hline 2008 & $2.61(.84)$ & $2.58(.84)$ & $2.65(.84)$ & -1.516 & .130 \\
\hline \multirow[t]{2}{*}{2013} & $3.26(.90)$ & $3.27(.91)$ & $3.25(.90)$ & .438 & 661 \\
\hline & $2008<2013 * * *$ & $F 08<F 13^{* * * *}$ & $M 08<M 13 * * *$ & & \\
\hline \multicolumn{6}{|c|}{ Iniversity culture/atmosphere } \\
\hline 2013 & $3.38(.76)$ & $3.40(.76)$ & $3.35(.76)$ & 1.037 & .300 \\
\hline \multicolumn{6}{|c|}{ ocial and educational facilities } \\
\hline 2013 & $3.09(.83)$ & $3.06(.81)$ & $3.13(.85)$ & -1.660 & .097 \\
\hline \multicolumn{6}{|c|}{ ducational process } \\
\hline 2013 & $3.43(.76)$ & $3.46(.76)$ & $3.40(.76)$ & 1.585 & .113 \\
\hline
\end{tabular}

$* p \leq .05 ; * * p \leq .01 ; * * * p \leq .001$; italic represents statistically important differences between 2008 and 2013

It identified both the determinants behind tertiary education choice motives, and it confirmed that those motives indeed change over time and that those changes are consistent with the evolution of demographic and economic conditions of a given market. Below we discuss our key findings. 
Table 7 Determinants of the university choice controlled for university type

\begin{tabular}{|c|c|c|c|c|}
\hline $\begin{array}{l}\text { University Choice } \\
(2008 \text { and 2013) }\end{array}$ & $\begin{array}{l}\text { Public } \\
P(\sigma) \\
N=760(2008) \\
N=810(2013)\end{array}$ & $\begin{array}{l}\text { Nonpublic } \\
N P(\sigma) \\
N=635(2008) \\
N=760(2013)\end{array}$ & $t$ statistic & $p$ value \\
\hline
\end{tabular}

Professional advancement

$\begin{array}{lllrl}2008 & 2.89(.97) & 3.15(.1 .03) & -4.575^{* * *} & .000 \\ 2013 & 3.05(.89) & 2.78(.88) & 6.022^{* * *} & .000 \\ & P 08<P 13^{* *} & N P 08>N P 13^{* * *} & & \end{array}$

University tradition

$\begin{array}{lllll}2008 & 2.95(.83) & 2.97(.80) & -.6 & .55 \\ 2013 & 3.22(.81) & 3.12(.76) & 2.458^{*} & .014 \\ & P 08<P 13 * * * & N P 08<N P 13 * * * & \end{array}$

University reputation

$\begin{array}{lllll}2008 & 2.00(.62) & 2.21(.70) & -6.054 * * * & .000 \\ 2013 & 3.74(.59) & 3.87(.60) & -4.452 * * * & .000 \\ & P 08<P 13 * * * & N P 08<N P 13 * * * & & \end{array}$

Marketing efforts

$\begin{array}{lllcr}2008 & 2.86(.77) & 2.73(.77) & 3.173 * * * & 0 \\ 2013 & 3.00(.87) & 2.98(.82) & .647 & .518 \\ & P 08<P 13 * * * & N P 08<N P 13 * * * & & \end{array}$

Courses offered

$\begin{array}{lllrl}2008 & 1.95(.55) & 2.00(.54) & -1.579 & .11 \\ 2013 & 3.93(.68) & 3.76(.64) & 5.180^{* * *} & .000 \\ & P 08<P 13^{* * *} & N P 08<N P 13^{* * *} & & \end{array}$

Cost of studies and accessibility of financial aid

\begin{tabular}{|c|c|c|c|c|}
\hline 2008 & $2.04(.97)$ & $1.92(.86)$ & $2.307 *$ & .021 \\
\hline \multirow[t]{2}{*}{2013} & $3.59(.82)$ & $3.67(.77)$ & -1.871 & .062 \\
\hline & $P 08<P 13^{* * *}$ & $N P 08<N P 13 * * *$ & & \\
\hline \multicolumn{5}{|c|}{ Tamily opinion and expectation } \\
\hline 2008 & $2.59(.81)$ & $2.64(.69)$ & -1.268 & .205 \\
\hline \multirow[t]{2}{*}{2013} & $3.32(.91)$ & $3.21(.90)$ & $2.356^{*}$ & .019 \\
\hline & $P 08<P 13 * * *$ & $N P 08<N P 13 * * *$ & & \\
\hline \multicolumn{5}{|c|}{ Jniversity culture/atmosphere } \\
\hline 2013 & $3.42(.76)$ & $3.34(.75)$ & 1.871 & .061 \\
\hline \multicolumn{5}{|c|}{ ocial and educational facilities } \\
\hline 2013 & $3.17(.82)$ & $3.01(.82)$ & $3.998 * * *$ & .000 \\
\hline \multicolumn{5}{|c|}{ ducational process } \\
\hline 2013 & $3.40(.78)$ & $3.48(.74)$ & $-1.940^{*}$ & .053 \\
\hline
\end{tabular}

$* p \leq .05 ; * * p \leq .01 ; * * * p \leq .001$; italic represents statistically important differences between 2008 and 2013

Our comparative study showed several implications for both stages of the decision making process. First, with regard to the decision of pursuing tertiary business education, two new factors emerged in 2013 study-recognition and prestige and gaining work experience during studies, with the first factor achieving the highest mean of all other 
factors. Second, recognition and prestige was followed by professional advancement and better chances to find a job, placing those three factors at the top of all factors considered while making a choice to pursue business education. Those factors were the most important regardless of gender or type of university (public vs. non-public). Third, a shift of the key choice factors was observed when compared to 2008 when students paid more attention to student-type of life and family opinion and expectations. From all these results we can notice that short-term orientation of having a great time while studying was switched to a long-term career orientation. The reasons behind those shifts might come from economical changes observed in Poland in 2012 which as mentioned in the introduction section of this article differed from those of 2008. As the consequence, choosing business education from the prestigious university emerged as a key factor increasing future employment opportunities. Also it is noticed that students follow family expectations to a much lesser degree, and indeed these are market requirements that influenced their decisions, not family suggestions.

Fourth, with regard to the choice of the specific university, three new factors were added in 2013-university culture/atmosphere, educational process and social and educational facilities (operationalized through application of digital and mobile technologies and social media), with the first two being placed among top five determinants of the university choice. We can therefore notice the increasing role of distinctive identity of the specific university observed in unique values and culture, and more importance given to the sense of community and networks. On the other hand, much more focus on educational process and more progressive models of acquiring knowledge with the use of digital technologies, may increase the pressure on universities to focus more on the merit of their teaching and learning methodologies and practices, as well as to seek ways to incorporate what Brinkworth et al. (2009) call "greater intellectual and social integration" in their educational process. Our respondents reported strong preference for being "connected" to their peer ecosystem through social media (Riedling 2007; Ehmann et al. 2012), expecting more innovative university facilities that will help them to exist in the university network, as well as to assist them in independent investigations, more self-learning activities, and participation in more experimental projects.

Fifth, regardless of gender or type of university, when choosing targeted university students paid most attention to courses offered, university reputation, and cost of studies and accessibility of financial aid. The means of those factors increased by over $80 \%$ in 2013 when compared to 2008. It should be noted that in 2008 the key three determinants were: professional advancement, university tradition, and marketing efforts, which in 2013 were at the bottom of the list. The priority of "courses offered" support the notion of other researchers (see Mason et al. 2003) that the new generation that enters the university pay much more attention to the merit of their studies which will help them in the future to boost their employability skills giving higher returns on their investments. Moreover, the implementation of National Qualifications Framework that started in 2008 (in 2012 for business studies) made universities prepare their offer in a more visible, streamlined and standardised manner, which combined with increasing marketing efforts could also impact changes in students' choices.

Our findings showed also that university reputation gained much more significance for university choice. Slowdown of Polish economy and freeze in hiring that was noticed in 2012 in most big companies in Poland along with increasing unemployment, made it more difficult for university graduates to find a job, and the diploma from the best universities, with proven academic credentials increased the employment 
opportunities. Indeed, as Kwiek (2013) noticed, during the expansion period (two decades of increase of non-public universities between 1990 and 2010) the recognition of differentiation between higher education institutions in Poland was low and higher education credentials from any institutional type were "viewed as a ticket to good lives and rewarding jobs" (pp. 559). However, with increasing economic crisis and high saturation of the educational sector, the qualitative differentiation became much more evident.

What attracted our attention is the convergence of opinions of men and women in both stages of the decision-making process. Increasing involvement of female students in Polish higher education (Kwiek 2013) and increasing balance in gender participation in different forms of public and business life (like parliamentary participation, participation on boards, equal employment rates, or much below EU-27 pay gap between men and women in Poland), raising awareness campaigns aimed at promoting female participation and equality of rights, might have contributed to decreasing differences between men and women in university choice preferences in 2013 when compared to 2008, although confirmation of this causal relation requires further investigation (Women in economic decision-making in the EU: Progress report 2012; Progress on equality between women and men in 2011, 2012).

Our study showed that students of public and non-public universities presented the same preferences with regard to key choice determinants. While choosing tertiary education, in 2013 both groups of respondents considered as key factors-recognition and prestige, professional advancement, and better chances to find a job. However, better chances to find a job was more important for those who targeted public universities, and we also noticed such difference with regard to the other factor-gaining work experience during studies. We can assume that those students who find the importance of those two factors as crucial in their decisions, more often choose public universities, because indeed in Poland public universities, which are much bigger and financially stable, usually cooperate more with a wide range of businesses which results in much bigger offer of internships that those schools provide.

While choosing university, primary factors considered by those who targeted both public and non-public university were: courses offered, university reputation, and cost of studies and accessibility of financial aid. In both cases their importance increased significantly in 2013 while compared to 2008. We could also observe that courses offered emerged as a more important factor for students choosing public university. In Poland non-public universities are much smaller when compared to public universities and usually offer no more than four majors. Therefore, those who choose to study in nonpublic university might consider variety of courses offered as less important. Although the importance of university reputation grew for all respondents in 2013, the value of this factor differs among both groups of respondents-like in 2008 it was more important for those targeting non-public schools. We attribute those results to the uncertainty with regard to the alarming predictions of educational market and financial stability of nonpublic universities. The university reputation is more important as a choice factor as it can influence a higher probability that a specific non-public university will survive on the market. Unsurprisingly, those students pay also more attention to innovative educational process, as it is their own knowledge and skills that increase their employment opportunities, while the value of their diploma might change radically when their university closes down. 


\section{Limitations and implications of the study}

This study has some limitations. First, it was limited only to students of business majors and therefore we admit that decisions of other groups of students can be led by different factors, which would require further studies in this field. Second, although our study shed light on the dynamism of student choices, they might be applicable only in the specific context of Poland and might not be generalizable to other markets. We believe that more work is now to be called for similar research that would compare student choices under changing market conditions and demographic shifts.

Despite above limitations, the findings of our study are a vital contribution to our understanding of the choice factors that lead students in their decisions in the process of transition from secondary to tertiary education. Poland with its biggest higher education system in Central-Eastern Europe may provide relevant information for all countries in the region that go through similar public/private dynamics and demographic shifts. This study confirms the dynamism of students' choices in both stages of the decision making process-pursuing tertiary education and the university choice. It is clear that university management should pay close attention to all economic and demographic changes which might impact determinants behind student decisions and continuously monitor the dynamism of preferences of their potential "customers". As Brinkworth et al. (2009) suggested, proactivity and earlier interventionist strategies should be constantly applied and the ability to understand the dynamism of student choices are the key issue in increasing enrollments.

Open Access This article is distributed under the terms of the Creative Commons Attribution License which permits any use, distribution, and reproduction in any medium, provided the original author(s) and the source are credited.

\section{References}

Antonowicz, D., \& Gorlewski, B. (2011). Demograficzne Tsunami. Warsaw: Instytut Rozwoju Kapitału Intelektualnego im. Sokratesa.

Brinkworth, R., McCann, B., Matthews, C., \& Nordström, K. (2009). First year expectations and experiences: Student and teacher perspectives. Higher Education, 58(2), 157-173.

Brown, R. M., \& Mazzarol, T. W. (2009). The importance of institutional image to student satisfaction and loyalty within higher education. Higher Education, 58, 81-95.

Cabrera, A. F., Vries, W., \& Anderson, S. (2008). Job satisfaction among Mexican alumni: A case of incongruence between hunch-based policies and labor market demands. Higher Education, 56(6), $699-722$.

Cea, F., \& Mora, J. G. (1992). Analisis socioeconomico de la demanda de Estudios Superiores. Estadistica Espanola, 129, 61-92.

Central Statistical Office of Poland (CSOP). (2009). Statistical yearbook of the Republic of Poland. Warsaw: Statistical Publishing Establishment.

Central Statistical Office of Poland (CSOP). (2010). Statistical yearbook of the Republic of Poland. Warsaw: Statistical Publishing Establishment.

Central Statistical Office of Poland (CSOP). (2013). Statistical yearbook of the Republic of Poland. Warsaw: Statistical Publishing Establishment.

Chapman, R. G. (1986). Toward a theory of college selection: A model of college search and choice behavior. Advances in Consumer Research, 13, 246-250.

Chen, L.-H. (2007). Choosing Canadian graduate schools from afar: East Asian students' perspectives. Higher Education, 54(5), 759-780.

Cremonini, L., Westerheijden, D., \& Enders, J. (2008). Disseminating the right information to the right audience: Cultural determinants in the use (and misuse) of rankings. Higher Education, 55(3), $373-385$. 
Douglas, J., Douglas, A., \& Barnes, B. (2006). Measuring student satisfaction at a UK university. Quality Assurance in Education, 14(3), 251-267.

Ehmann, S., Borges, S., \& Klanten, R. (2012). Learn for life. New architecture for new learning. Berlin: Gestalten.

Elster, J. (1999). Alchemies of the mind: Rationality and the emotions. Cambridge: Cambridge University Press.

Ernst\&Young and Instytut Badań nad Gospodarką Rynkową. (2010). Strategia rozwoju szkolnictwa wyższego w Polsce do 2020 roku. Warsaw: Instytut Badań nad Gospodarką Rynkową.

European Economic Forecast (2012). European Economy, 7, 1-179.

Eurostat (2010). Europe in figures. Eurostat yearbook, 1-664.

Gonzalez, B., \& Davila, D. (1998). Economic and cultural impediments to University Education in Spain. Economics of Education Review, 17, 93-103.

Hanson, K., \& Litten, L. (1982). Mapping the road to academia: A review of research on women, men, and the college selection process. In P. Perun (Ed.), The undergraduate woman: Issues in education. Lexington, MA: Lexington Books.

Hossler, D., \& Gallagher, K. S. (1987). Studying student college choice: A three-phase model and implications for policy makers. College and University, 2, 207-221.

Hossler, D., Schmit, J., \& Vesper, N. (1999). Going to college: How social, economic, and educational factors influence the decisions students make. Baltimore: Johns Hopkins University Press.

Hung, F.-S., Chung, Y.-P., \& Ho, E. S.-C. (2000). To work or to continue to higher education? The choice of senior secondary students in Shenzhen, China. Higher Education, 39, 455-467.

International Quarterly Statistics (2008). Warsaw: Central Statistical Office of Poland, pp. 1-110.

Jackson, G. A. (1982). Public efficiency and non-public choice in higher education. Educational Evaluation and Policy Analysis, 4(2), 237-247.

Jimenez, J., \& Salas-Velasco, M. (2000). Modeling educational choices. A binomial logit model applied to the demand for higher education. Higher Education, 40, 293-311.

Kohn, M., Manski, C., \& Mundel, D. (1976). An empirical investigation of factors which influence college going behavior. Annals of Economic and Social Measurement, 5, 391-419.

Koivula, J., \& Rinne, R. (2006). The dilemmas of the changing university. Turku: European Universities for Entrepreneurship.

Kwiek, M. (2013). From system expansion to system contraction: Access to higher education in Poland. Comparative Education Review, 57(3), 553-576.

Maringe, F. (2006). University and course choice: Implications for positioning, recruitment and marketing. International Journal of Educational Management, 20(6), 466-479.

Mason, G., Williams, G., Cranmer, S., \& Guile, S. (2003). How much does higher education enhance the employability of graduates? Report to HEFCE. Bristol: Higher Education Funding Council for England.

McCoy, S., \& Smyth, E. (2010). Higher education expansion and differentiation in the Republic of Ireland. Higher Education, 61(3), 243-260.

Menon, M. (2004). Information search as an indication of rationality in student choice of higher education. Higher Education, 12(3), 267-283.

Menon, M. E., Saiti, A., \& Socratous, M. (2007). Rationality, information search and choice in higher education: Evidence from Greece. Higher Education, 54, 705-721.

Mintzberg, H., Raisinghani, D., \& Theoret, A. (1976). The structure of "unstructured” decision processes. Administrative Science Quarterly, 21, 246-275.

Newsweek 12.11.2012. Szkoły wyższe - czeka nas fala upadtości?. http://spoleczenstwo.newsweek.pl.

OECD. (2008). Higher education to 2030 (Vol. 1)., Demography Paris: OECD Publishing.

OECD. (2009). Higher education to 2030 (Vol. 2)., Globalization Paris: OECD Publishing.

Pimpa, N. (2005). A family affair: The effect of family on Thai students' choices of international education. Higher Education, 49(4), 431-448.

Progress on equality between women and men in 2011 (2012) Luxembourg: European Commission, Publications Office of the European Union, pp 1-44.

Riedling, A.M. (2007). An educator's guide to information literacy: What every high school senior needs to know. Libraries Unlimited.

Rozanski, A. (2008). The educational orientation of participants in postgraduate managerial study programs in Poland. Human Resource Development International, 11(1), 91-99.

Skuza, A., Scullion, H., \& McDonnell, A. (2013). An analysis of the talent management challenges in a post-communist country: The case of Poland. The International Journal of Human Resource Management, 24, 453-470. 
Sojkin, B., Bartkowiak, P., \& Skuza, A. (2012). Determinants of higher education choices and student satisfaction: The case of Poland. Higher Education, 63(5), 565-581.

Somers, P., Cofer, J,. \& Putten, J.V. (1999). The influence of early aspirations and attitudes on postsecondary attendance. In American Educational Research Association Conference, Montreal, Canada.

Sullivan, A. (2006). Students as rational decision-makers: The question of beliefs and attitudes. London Review of Education, 4(3), 271-290.

United Nation Report. (2005). World population prospects. The 2004 revision. New York: United Nations.

Wedley, W. C., \& Field, R. H. G. (1984). A pre-decision support system. Academy of Management Review, 9, 696-703.

Women in economic decision-making in the EU: Progress report. (2012). Luxembourg: European Commission, Publications Office of the European Union, pp 1-24.

Wong, A. (1989), Perceived earnings functions and ex ante rates of return to higher education. Doctoral Dissertation, University of London. 